\title{
Cartilage proteoglycan-specific T cells as vectors of immunomodulatory biologicals in chronic proteoglycan-induced arthritis
}

\author{
Teun Guichelaar ${ }^{\mathrm{a}, \mathrm{b}}$, Corlinda B. ten Brink ${ }^{\mathrm{a}}$, Peter J. van Kooten ${ }^{\mathrm{a}}$, Suzanne E. Berlo ${ }^{\mathrm{a}}$, \\ Floris P. Lafeber ${ }^{\mathrm{c}}$, Chris. P. Broeren ${ }^{\mathrm{a}}$, Willem van Eden ${ }^{\mathrm{a}}$, Femke Broere ${ }^{\mathrm{a}, *}$ \\ a Division of Immunology, Department of Infectious Diseases and Immunology, Utrecht University, Yalelaan 1, 3584 CL Utrecht, The Netherlands \\ ${ }^{\mathrm{b}}$ Department of Clinical Chemistry and Haematology, University Medical Center Utrecht, Heidelberglaan 100, Utrecht, The Netherlands \\ ${ }^{\mathrm{c}}$ Department of Rheumatology and Clinical Immunology, University Medical Center Utrecht, Heidelberglaan 100, Utrecht, The Netherlands
}

\section{A R T I C L E I N F O}

\section{Article history:}

Received 25 January 2008

Received in revised form 14 May 2008

Accepted 14 May 2008

Available online 24 June 2008

\section{Keywords:}

Th-cells

Arthritis

Cytokines

Gene therapy

\begin{abstract}
A B S T R A C T
Systemic administration of agents that neutralize or antagonize $T_{h} 1$-mediated pro-inflammatory responses has been demonstrated to ameliorate inflammation in chronic autoimmune disease. However, systemic administration of such immunosuppressive biologicals causes serious side effects and has only limited success. To minimize these side effects, autoantigen-specific lymphocytes have been proposed as a carrier to deliver immunosuppressive agents to sites of inflammation. Here we studied the effects of primary cartilage proteoglycan-specific $\mathrm{CD} 4^{+} \mathrm{T}$ cells that were transduced using an efficient method of viral transduction with active genes encoding IL- $1 \beta$ receptor antagonist, soluble TNF- $\alpha$ receptor-Ig, IL- 4 or IL-10 in chronic proteoglycan-induced arthritis in mice. This is the first study describing such gene therapy using primary $\mathrm{CD}^{+} \mathrm{T}$ cells in a chronic arthritis. Moreover, the impact of proteoglycan-specific $T_{h} 1, T_{h} 2$ or naïve $T$ cells was studied. Although proteoglycan-TCR transgenic CD4+ $T$ cells can transfer arthritis to lymphopenic recipients, none of the proteoglycan-TCR transgenic T cell phenotypes that were tested induced worsening of arthritis in wild type hosts. Proteoglycan-specific T cells ameliorated arthritis when expressing the transduced IL-10 gene, and not when expressing the other transgenes/phenotypes. Although all of the tested biologicals can suppress in a wide range of different inflammatory disorders, especially IL-10 would therefore serve as a promising candidate to be used in cellular gene therapy for chronic arthritis.
\end{abstract}

(C) 2008 Elsevier Ltd. All rights reserved.

\section{Introduction}

Rheumatoid arthritis (RA) is a systemic autoimmune disease exhibiting chronic inflammation in the synovia of the joints that leads to progressive destruction of articular tissue. In RA-patients the balance between expression of pro-inflammatory cytokines and their inhibitors has shifted to that of an aggressive proinflammatory response. In addition, extensive studies in animal models indicate that tissue antigen (cartilage)-specific $\mathrm{CD}^{+} \mathrm{T}$ cells are pivotal in the pathogenesis of arthritis (Glant et al., 2003; Brand et al., 2003). Moreover, human studies have shown that $\mathrm{T}$ cells from patients with RA respond to cartilage antigens like proteoglycan (PG) (Goodstone et al., 1996; Guerassimov et al., 1998; Li et al., 2000; ter Steege et al., 2003). Thus, T cell immunity in RA seems dominated by a $T_{h} 1$ response that may have escaped immune regulation by $T_{\text {reg }}$ or counteracting $T_{h} 2$

\footnotetext{
* Corresponding author. Fax: +31 302533555

E-mail address: F.Broere@uu.nl (F. Broere).
}

responses (Skapenko et al., 2005). Synovial inflammation is dominated by high concentrations of TNF- $\alpha$ and IL-1 $\beta$ (McInnes and Schett, 2007) produced by synovial fibroblasts, mediating joint inflammation and destruction by production of catabolic metalloproteinases.

Biological agents neutralizing activity of pro-inflammatory cytokines such as IL-1 receptor antagonist (IL-1RA), anti-TNF- $\alpha$ antibody and soluble TNF- $\alpha$ receptors can exert considerable beneficial clinical effects in patients (van de Loo et al., 2004). In addition, treatment with cytokines like IL- 4 and IL-10 that are known to down-regulate $T_{h} 1$ responses has been proven beneficial in several models of RA (van de Loo et al., 2004; Finnegan et al., 1999). However, alleviation of clinical disease outcome by systemic administration of such agents is accompanied by a high risk for adverse reactions. A major problem is the increased susceptibility to serious infection due to systemic immunosuppression (Weisman, 2002). To avoid such unwanted effects, vectors that target immunosuppressive drugs to the site of the autoantigen-specific response may be a useful alternative for the treatment of autoimmune mediated disease. 
Because $\mathrm{CD}^{+}{ }^{+} \mathrm{T}$ cells carry an antigen specific TCR, they have the ability to recognize antigens and interfere with certain immune responses in an antigen-specific manner. For this reason $\mathrm{CD} 4^{+} \mathrm{T}$ cells that recognize tissue-specific autoantigens have been proposed as vectors that can be deployed to specifically target the pro-inflammatory autoimmune response with immunomodulatory agents (Robbins et al., 2003; Tarner et al., 2003). This concept was first successfully demonstrated in experimental autoimmune encephalomyelitis, a model for multiple sclerosis, in which a myelin-specific $\mathrm{T}$ cell line transduced with a gene encoding nerve growth factor exerted anti-inflammatory effects (Kramer et al., 1995). Promising possibilities of this so-called adoptive T-cellbased gene therapy have now become demonstrated for a wide range of different molecules in several models of autoimmunity and also of allergy (Robbins et al., 2003; Tarner et al., 2003; Oh et al., 2002).

In many studies either T cell hybridoma's or T cells with rather undefined antigen-specificities were used as carriers. The study presented here describes for the first time T-cell-based gene therapy with immunosuppressive proteins expressed by primary $\mathrm{CD} 4^{+}$ $\mathrm{T}$ cells with a defined specificity for cartilage-derived antigen in a chronic model of RA. We transduced proteoglycan-specific CD4 ${ }^{+}$ cells from a TCR-transgenic mouse (Berlo et al., 2006, 2005) with TNF- $\alpha$ receptor-Ig, IL-1 receptor antagonist, IL- 4 or IL-10 and tested the immunomodulatory capacities of these $\mathrm{CD} 4^{+}$cells in cartilage proteoglycan-induced arthritis (PGIA). The progressive inflammation in PGIA is caused by $\mathrm{T}_{\mathrm{h}} 1$ immunity (Finnegan et al., 1999; Hollo et al., 2000; Kaplan et al., 2002), depends on B cells (O'Neill et al., 2005) and bears similarities with clinical features and genetics of RA as reviewed in Glant et al. (2003). In addition to transduction with modulatory genes, PG-specific T cells were forced to differentiate into either $T_{h} 1$ or $T_{h} 2$ cells ex vivo in the presence of immune deviating cytokines and then transferred to test their impact on PGIA. Although PG-specific T cells are arthritogenic (Berlo et al., 2006, 2005; Buzas et al., 1995) in lymphopenic hosts, naïve or $T_{h} 1$ PG-specific T cells, as well as the other phenotypes that were tested, did not add to severity of arthritis when transferred in PGIA in wild type hosts. Surprisingly, most T cells expressing the different transgenes encoding well known immunosuppressive agents did not suppress arthritis. However, PG-specific T cells transduced with the active IL-10 gene significantly reduced both arthritis severity and arthritis incidence, indicating IL-10 as a very powerful immunosuppressive cytokine to be used in (adoptive gene) therapy.

\section{Materials and methods}

\subsection{Mice and antigens}

Retired breeder BALB/c mice (Charles River Laboratories, Maastricht, The Netherlands) were kept at the animal facility of the University of Utrecht; "Gemeenschappelijk Dierenlaboratorium" (GDL) under standard conditions in filtertopped cages. TCR-5/4E8Tg BALB/c (PG-TCR Tg) mice (Berlo et al., 2006, 2005) and DO11.10 mice were bred and kept at the GDL under specific pathogen free conditions. Human PG (hPG) and were prepared as described elsewhere (Hanyecz et al., 2004). All animal experiments were approved by the Animal Experimental Committee of the Veterinary Faculty of the University of Utrecht.

\subsection{Generation of retroviral constructs}

DNA sequences encoding IL-10, IL-4, TNF $\alpha$ receptor Ig, and IL-1 $\beta$ receptor antagonist were generated as described below and cloned into the MSCV2.2 plasmid. mRNA was isolated from Balb/c cells and reversely transcribed to the cDNA that was used as template for all specific amplifications with PCR.

Murine IL-10 cDNA was amplified using primers F 5'-AGA TCT TTG CAG AAA AGA GAG CTC CA-3' and R 5'-GTC GAC TGG AGT CCA GCA GAC TCA AT- $3^{\prime}$, murine IL-4 CDNA was amplified using the primers F 5'-ACG GCA CAG AGC TAG TGA TG-3' and R 5'-GTC GAC AAG TTA AAG CAT GGT GGC TCA-3'. Murine IL-1 $\beta R A$ was amplified using primers F 5'-CTC GGG ATG GAA ATC TGC T- $3^{\prime}$ and $5^{\prime}$-GTC GAC TTA TTA CAG GCC TCG GCA GT-3', TNFR cDNA was amplified using primers $\mathrm{F}$ 5'-GCG GCC GCC AAT GGG GGA GTG AGG-3' and R 5'-TCT AGA GGG GTT TGT GAC ATT TGC AAG C-3'. The amplified TNFR cDNA was BAMHI/Sall restricted and cloned into $\mathrm{pEDMIgG}_{2 \mathrm{a}}$ mut + L to generate the TNFRIgG sequence. Amplified products were sequenced to confirm sequences.

\subsection{Production of retrovirus}

Ecotropic replication-deficient retrovirus was produced with a Phoenix-Eco packager cell line. Packager cells were cultured per $3 \times 10^{6}$ cells in $10 \mathrm{ml}$ complete DMEM (Gibco Life Technologies, Breda, The Netherlands) at $37^{\circ} \mathrm{C}$. The next day the culture medium was refreshed and $500 \mu \mathrm{l}$ of $0.25 \mathrm{M} \mathrm{CaCl}_{2}$ containing $20 \mu \mathrm{g} \mathrm{MSCV-}$ plasmid $+5 \mu \mathrm{g}$ PCL-Eco plasmid was mixed with an equal volume HBS buffer pH 7.02 and added to the cells. At $20 \mathrm{~h}$ after transfection supernatant was replaced with fresh medium. After 24 and $48 \mathrm{~h}$, supernatant containing the retrovirus was harvested, filtered with a $0.45 \mu \mathrm{M}$ filter and stored frozen until use. Prior to T cell transductions, retroviral activity was tested on NIH3T3 cells using the protocol that was used for $\mathrm{T}$ cell transfection 1 day after seeding the $3 \mathrm{~T} 3$ cells at a concentration of $3 \times 10^{4} \mathrm{ml}^{-1}$ in supplemented DMEM.

\subsection{Stimulation, retroviral transduction and transfer of transduced $C D 4^{+}$T cells}

$\mathrm{CD}^{+}{ }^{+} \mathrm{T}$ cells were isolated from pooled spleens and lymph nodes of TCR-5/4E8-Tg BALB/c with anti-CD4 (L3T4) magnetic microbeads using the manufacturer's protocol (MACS, Miltenyi Biotec $\mathrm{GmbH}$, Bergisch Gladbach, Germany) and stimulated with magnetic M450 Tosylactivated Dynabeads (Dynal Biotech ASA, Oslo, Norway) coated with anti-CD3 (145-2C11) and anti-CD28 (PV-1) mAbs in a $1: 10$ ratio. Anti-CD3/anti-CD28 mAb-coated beads were added to $1 \times 10^{6} \mathrm{CD}^{+} \mathrm{T}$ cells (in a 2:1 ratio). After $48 \mathrm{~h}$ of culturing, $750 \mu \mathrm{l}$ of the culture supernatant was replaced with $1 \mathrm{ml}$ of retroviral supernatant supplemented with $8 \mu \mathrm{g} / \mathrm{ml}$ hexadimethrine bromide (Sigma-Aldrich Chemie BV, Zwijndrecht, The Netherlands) for retroviral infection. Plates were then centrifuged at $930 \times \mathrm{g}$ at $20^{\circ} \mathrm{C}$ for $2 \mathrm{~h}$. Subsequently, $1 \mathrm{ml}$ of supernatant was replaced with fresh medium and cells were cultured for another $48 \mathrm{~h}$. Cells were removed from the stimulating beads and transduced cells were sorted by GFP expression with a FACSVantage SE (Becton Dickinson) before transfer. Per recipient $1 \times 10^{6}$ transduced $C D 4^{+}$cells were injected i.p. in PBS.

\subsection{Differentiation of $T_{h} 1$ and $T_{h} 2$ cells}

$\mathrm{CD} 4{ }^{+} \mathrm{T}$ cells from pooled spleens and lymph nodes of TCR-5/4E8$\mathrm{Tg} \mathrm{BALB} / \mathrm{c}$ were isolated and activated as described for retroviral transduction. For differentiation to a $\mathrm{T}_{\mathrm{h}} 1$-phenotype $10 \mathrm{ng} / \mathrm{ml}$ recombinant mouse IL-12p70 (BD Pharmingen) and $10 \mu \mathrm{g} / \mathrm{ml}$ antiIL-4 mAb (11B11) were added to the culture. For differentiation to a $\mathrm{T}_{\mathrm{h}}$ 2-phenotype $20 \mathrm{ng} / \mathrm{ml}$ recombinant mouse IL-4 (BD Pharmingen) and $10 \mu \mathrm{g} / \mathrm{ml}$ anti-IFN- $\gamma$ mAb (XMG1.2) were added to the culture. After 4 days of stimulation, cells were removed from the stimulating beads and prepared for phenotyping by flow cytome- 
try or washed for transfer as described for transduced cells. After $\mathrm{T}_{\mathrm{h}} 1$ - or $\mathrm{T}_{\mathrm{h}} 2$-differentiation protocols blastoid cells were gated as was done for sorting of transduced cells and sorted for transfer. Per recipient $1 \times 10^{6} \mathrm{CD}^{+}$cells were injected i.p. in PBS.

\subsection{Analysis of transgene expression}

Anti-TNF- $\alpha$ activity of TNF $\alpha$ R-Ig was assessed using the WEHI164 cytotoxicity bioassay as previously described (Espevik and Nissen-Meyer, 1986). Alamar Blue was used to assess cell viability at OD 550/595. Activity of IL-1RA was assessed using a NF-кB-luciferase bioassay (Smeets et al., 2005). IL-4 and IL-10 were measured using fluoresceinated microspheres coated with ELISA capture antibodies (BD Pharmingen) as described elsewhere (Berlo et al., 2006) with a Luminex model 100 (Luminex, Austin, TX).

\subsection{In vitro testing for immunosuppression}

To generate dendritic cells (DC), bone marrow cells from wild type Balb/c mice were seeded at $2 \times 10^{6}$ per $100 \mathrm{~mm}$ suspension dish (Corning) in $10 \mathrm{ml}$ supplemented IMDM (Gibco) with $20 \mathrm{ng} / \mathrm{ml}$ rGM-CSF (Cytocen, Utrecht). At day 3, $10 \mathrm{ml}$ supplemented IMDM with $20 \mathrm{ng} / \mathrm{ml} \mathrm{rGM-CSF}$ was added. At day $6,10 \mathrm{ng} / \mathrm{ml} \mathrm{rGM-CSF}$ was added. At day 8 the non-adherent cells were harvested, washed and either used as APC for T cells in a proliferation assay or stimulated with LPS (Sigma-Aldrich) to determine IL-12p70 production. OVAspecific $\mathrm{CD}^{+}{ }^{+}$responder cells were isolated from pooled spleen and lymph node cells of DO11.10 mice by negative selection with Dynabeads (Dynal) using an excess of anti-B220 (RA3-6B2), antiCD11b (M1/70), anti-MHC class-II (M5/114) and anti-CD8 (YTS169) $\mathrm{mAbs}$ and were labelled with CFSE (Molecular Probes, Leiden, The Netherlands). The proliferation assays were done in 96-well flat bottom plates (Corning) with $2 \times 10^{5}$ CFSE-labelled DO11.10 $\mathrm{CD}^{+}$cells and $2.5 \times 10^{4}$ bone marrow-derived BALB/c DCs cultured in the presence of $0.32 \mu \mathrm{g} / \mathrm{ml} \mathrm{OVA}_{323-339}$ peptide in $200 \mu \mathrm{l}$ supplemented IMDM during 4 days. Intracellular IL-12p70 production by DC was analyzed after $24 \mathrm{~h}$ of stimulation with LPS. Brefeldin A was present during the final $4 \mathrm{~h}$ of LPS-stimulation to allow cytokine detection by flow cytometry. To analyze the suppressive activity of culture supernatant, $50 \mu \mathrm{l}$ of the final culture medium consisted of conditioned supernatant taken from transduced $\mathrm{T}$ cells. Blocking of IL-10 activity was done by adding $100 \mu \mathrm{g} / \mathrm{ml}$ of a neutralizing anti-IL-10 mAb (JES-2A5) to the cell cultures.

\subsection{Flow cytometry}

For flow cytometry of surface marker and GFP expression, cells were washed and stained with allophycocyanin (APC) or phycoerythrin (PE)-conjugated anti-CD4 mAb (BD Pharmingen), thoroughly washed with PBS/2\% FCS and fixed in 4\% paraformaldehyde (PFA; Sigma-Aldrich Chemie BV). For analysis of intracellular IFN- $\gamma$ and IL-4 in T cells, the cells were washed and stimulated prior to staining as described in Openshaw et al. (1995) at $10^{6} \mathrm{ml}^{-1}$ with $50 \mathrm{ng} / \mathrm{ml}$ PMA (Sigma-Aldrich Chemie BV) and $500 \mathrm{ng} / \mathrm{ml}$ ionomycin (Sigma-Aldrich Chemie BV) for $4 \mathrm{~h}$ with Brefeldin A (Sigma-Aldrich Chemie BV) added at $10 \mu \mathrm{g} / \mathrm{ml}$ after the first $2 \mathrm{~h}$ of stimulation. Before staining for intracellular cytokines cells were washed thoroughly, fixed in $4 \%$ PFA and washed again. Then cells were permeabilized with PBS/2\% FCS/0.5\% saponin and stained for intracellular cytokines with Fluorescein isothyocyanate (FITC)-conjugated anti-IL-4 mAb and PE-conjugated IFN- $\gamma \mathrm{mAb}$ (BD Pharmingen) or PE-conjugated IL-12p70 mAb (BD Pharmingen) in PBS/2\% FCS/0.5\% saponin (Sigma-Aldrich Chemie BV). After
3 washes cells were analyzed with a FacsCalibur flowcytometer (Becton Dickinson). Data were analyzed with Flow-Jo software.

\subsection{Induction and assessment of arthritis}

Arthritis was induced by i.p. injections of $2 \mathrm{mg}$ hPG (crude extract) emulsified in $2 \mathrm{mg}$ of the synthetic adjuvant dimethyldioctadecyl-ammoniumbromide (DDA) (Sigma) in PBS (total volume of $200 \mu \mathrm{l}$ ) on day 0 and day 21 as described elsewhere (Berlo et al., 2006; Hanyecz et al., 2004). Paws were examined three times per week in a blinded set-up to determine onset and severity of arthritis using a standard visual scoring system based on swelling and redness of the paws.

\subsection{Analysis of regulatory markers in IL-10 transduced T cells in PG-induced arthritis}

IL-10 transduced CD4 ${ }^{+}$T cells, or (GFP-transduced) control CD4 ${ }^{+}$ $\mathrm{T}$ cells, were isolated from recipient, PG-immunized mice with a FACS Vantage (Becton Dickinson) by sorting the $\mathrm{GFP}^{+} \mathrm{CD} 4^{+}$cell population from spleens after staining single cells with APC-conjugated CD4 mAb (BD Pharmingen). mRNA was extracted from these sorted cells (RNAeasy kit, Qiagen), DNAse-digested (Qiagen), and reversely transcribed to cDNA (iScript cDNA synthesis, Biorad). Using this cDNA as template, analysis of Foxp3, TGF- $\beta 1$ and HPRT mRNA expression was done by quantitative real-time PCR. This PCR was performed in a total volume of $25 \mu \mathrm{l}$ using iQ ${ }^{\mathrm{TM}}$ SYBR Green ${ }^{\circledR}$ Supermix (Bio-Rad) with a Bio-Rad MyiQ iCycler (Bio-Rad) using the following primers: Foxp3 (5'-CCC AGG AAA GAC AGC AAC CTT-3' and $5^{\prime}$-TTC TCA CAA CCA GGC CAC TTG-3'), TGF- $\beta 1$ ( $5^{\prime}$-GCC CTG TAT TCC GTC TCC TCC TTG- $3^{\prime}$ and $5^{\prime}$-CGT AAC CGG CTG CTG ACC-3') and HPRT ( $5^{\prime}$-CTG GTG AAA AGG ACC TCT CG-3' and 5'-TGA AGT ACT CAT TAT AGT CAA GGG CA-3'). Expression of Foxp3 and TGF$\beta 1$ mRNA was normalized to HPRT expression for quantification in different samples.

\subsection{Statistics}

Statistical analysis was done for comparison of T cell-recipients with the PBS-control group with a two-tailed $t$-test. $p$-Values less than 0.05 were considered significant. Unless stated otherwise, variation was shown as standard error of the means (S.E.M.).

\section{Results}

\subsection{Generation of genetic constructs and transduction of $C D 4^{+}$ cells}

To generate genetically modified cartilage antigen-specific $\mathrm{CD}^{+} \mathrm{T}$ cells, $\mathrm{CD}^{+}$cells from mice expressing a PG-specific TCR were retrovirally transduced with different genes encoding immunomodulatory proteins. PG-specific $\mathrm{CD} 4^{+}$cells were isolated from TCR-5/4E8-Tg BALB/c mice. In all experiments $>90 \%$ of the $\mathrm{CD} 4^{+}$cells express the V $\beta 4$ chain, which is part of the PG-specific 5/4E8-Tg TCR. Wild type littermates express V $\beta 4$-chains on only $6 \%$ of the $\mathrm{CD}^{+} \mathrm{T}$ cells (Berlo et al., 2006). Constructs that were designed for $\mathrm{T}$ cell transduction were generated by PCR on murine cDNA and cloned into the murine stem cell virus (MSCV) plasmid. Ecotropic replication deficient retrovirus was produced from transiently plasmid-transfected Phoenix-Eco producer cells that pack the designed construct into retroviral particles. The construct encodes the following sequence: LTR-cloning site-IRES-GFP-LTR (Fig. 1A). The LTR sequence enables stable genomic integration and contains promoter and enhancer activity for constant expression of cloned transgenes. Green fluorescent protein (GFP) allows for 
(A) MSCV-GFP
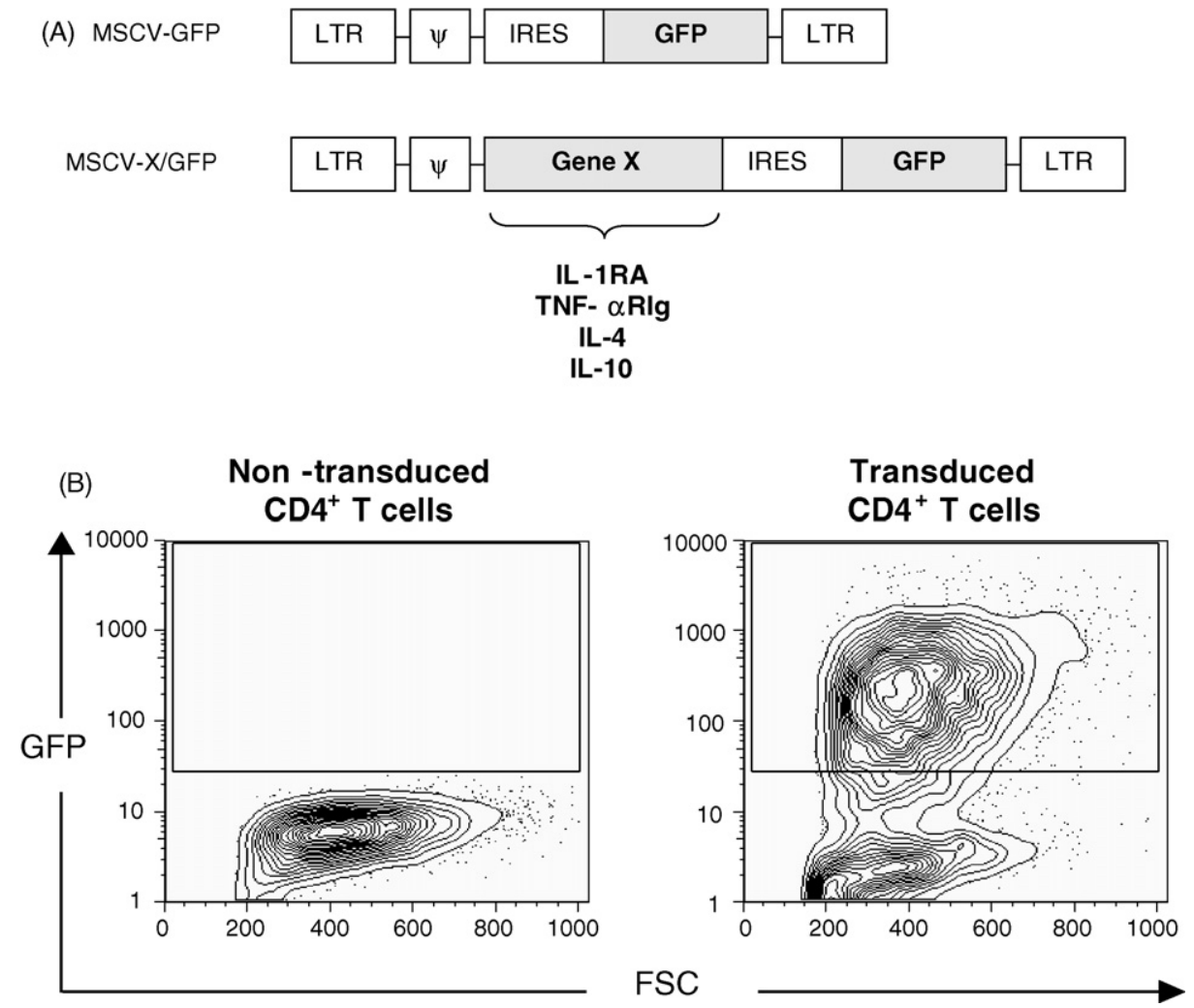

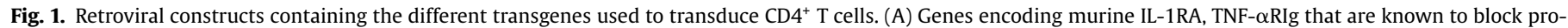

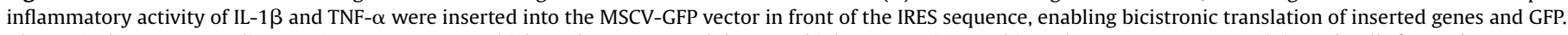

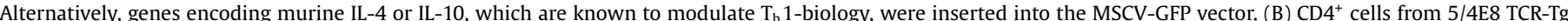

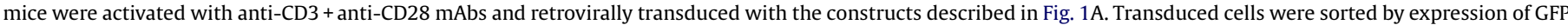

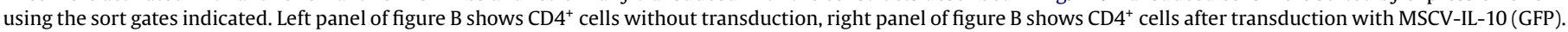

selection of transduced cells and is translated into a separate protein that is not conjugated to the immunomodulatory proteins due to the interribosomal entry site (IRES).

$\mathrm{T}$ cells must be in division to enable retroviral transduction (Costa et al., 2000) and were therefore activated in vitro to induce proliferation. To effectively induce $\mathrm{T}$ cell proliferation without the need for antigenic peptides and to circumvent the need to separate $\mathrm{T}$ cells from antigen presenting cells after stimulation and transduction we choose an APC-free T cell stimulation system. For this we used magnetic beads coated with anti-CD3 $\mathrm{mAb}$ and superagonistic anti-CD28 mAb as described earlier (Broeren et al., 2000). Using this protocol, numbers of T cells that were transduced ranged, depending on the transgene, from $55-80 \%$ of the $T$ cells as analyzed by flow cytometry of GFP expression (Fig. 1B). Transduction efficiencies for different transgenic constructs are listed in Table 1. $\mathrm{CD}^{+}$purity after 4 days of culturing was usually $>95 \%$. Transduced cells were sorted by GFP expression, especially those in the blastoid fraction observed in the forward scatter/side scatter (FSC/SSC)

Table 1

Transgene expression by transfected cells and transduction rates of TCR transgenic CD4 ${ }^{+}$T-cells

\begin{tabular}{|c|c|c|c|}
\hline $\begin{array}{l}\text { Transgene } \\
\text { from MSCV } \\
\text { vector }\end{array}$ & $\begin{array}{l}\text { Transgene expression } \\
\text { (secreted protein) } \\
(\mathrm{ng} / \mathrm{ml})\end{array}$ & $\begin{array}{l}\text { \%Transduction } \\
\left(\mathrm{GFP}^{+}\right) \text {of } \mathrm{CD}^{+} \\
\text {cells }(\%)\end{array}$ & $\begin{array}{l}\text { MFI of GFP in } \\
\text { transduced CD4 } \\
\text { cells }\end{array}$ \\
\hline IL-1RA & 20 & 86 & 627 \\
\hline TNF- $\alpha$ RIg & 147 & 55 & 70 \\
\hline IL-4 & 16 & 78 & 457 \\
\hline IL-10 & 11 & 73 & 370 \\
\hline GFP (control) & - & 80 & 1216 \\
\hline
\end{tabular}

plots. These sorted transduced cell populations used for transfer were $>99.5 \% \mathrm{GFP}^{+}$. Altogether, these results show that stimulation via the CD3/TCR-complex plus CD28-mediated co-stimulation with mAbs is a very efficient means to stimulate $T$ cells for retroviral transduction.

\subsection{Expression of transgenes}

In order to show that proteins encoded by the constructed transgenes were secreted and biologically active, culture supernatant of transfected cells was analyzed for the presence of these proteins (Table 1 ). To analyze for the presence of functional IL-1RA, neutralizing IL-1RA activity was measured with a luciferase-reporter assay for IL-1RA activity. Active IL-1RA was found at a concentration of $20 \mathrm{ng} / \mathrm{ml}$, indicating that biologically active IL-1RA was expressed from the MSCV-IL-1RA construct. Neutralizing activity of the constructed TNF- $\alpha$ RIg was analyzed with a TNF- $\alpha$-sensitive WEHI-164 celline cultured with different concentrations of murine TNF- $\alpha$ inducing different levels of apoptosis of the WEHI-164 cells. Supernatant of MSCV-TNF- $\alpha$ RIgGFP-transfected cells contained a blocking activity of $147 \mathrm{ng} / \mathrm{ml}$ murine TNF- $\alpha$ per milliliter compared with MSCV-GFP-transfection supernatant. Thus, the constructed TNF- $\alpha$ RIg encoded biologically active TNF- $\alpha$ RIg. To analyze expression of the cytokines IL-10 and IL-4, concentrations were measured in cell culture supernatant with a multiplex assay for quantification of protein expression. The concentrations of IL- 4 and IL-10 secreted were about the same level (16 and $11 \mathrm{ng} / \mathrm{ml}$ ) as IL-1RA. Altogether, these results show that all transgenes constructed were expressed and secreted. 


\section{3. $T_{h} 1 / T_{h} 2$-differentiation}

In order to stimulate differentiation of PG-specific T cells into $\mathrm{T}_{\mathrm{h}} 1$ or $\mathrm{T}_{\mathrm{h}} 2$, freshly isolated TCR-5/4E8-Tg CD4 ${ }^{+}$cells were stimulated with anti-CD3 and anti-CD28 mAbs in vitro. For differentiation into $\mathrm{T}_{\mathrm{h}} 1$ cells, $\mathrm{CD} 4^{+}$cells were stimulated in the presence of IL12 p70 and anti-IL- $4 \mathrm{mAb}$. To stimulate differentiation into $\mathrm{T}_{\mathrm{h}} 2$ cells, $\mathrm{PG}$-specific $\mathrm{CD} 4^{+}$cells were stimulated in the presence of IL- 4 and anti-IFN- $\gamma$ mAb. After 4 days of stimulation, cells within the blastoid population, as selected by the FSC/SSC profile of these cells, were sorted and transferred in PGIA as described later on. This was done in order to select for the stimulated cells from the in vitro culture, thus to avoid transfer of undifferentiated cells. Numbers of $\mathrm{CD}^{+}$cells expressing IFN- $\gamma(18.2 \%)$ exceeded the number of IL-4 producers (8.6\%) after anti-CD3/anti-CD28 stimulation in the absence of exogenous cytokines or cytokine-antibodies as analyzed at the cellular level by flow cytometry. The $T_{h} 1$-skewing factors almost completely reduced this number of cells producing IL-4 $(0.8 \%)$, while the number of IFN- $\gamma$-producers had doubled (34.6\%). In the presence of $\mathrm{T}_{\mathrm{h}} 2$-differentiation factors the number of cells producing IFN- $\gamma(8.2 \%)$ was reduced, while the number of IL- 4 producers had increased more than three-fold (29.6\%).

\subsection{Pro-inflammatory effects of PG-specific T cells in PGIA}

Arthritis is dominated by autoantigen-specific $\mathrm{CD}^{+} \mathrm{T}$ cells which are characterized by a $\mathrm{T}_{\mathrm{h} 1}$ phenotype. The arthritogenic role for cartilage antigen-specific $\mathrm{T}$ cells was demonstrated also by an increased susceptibility for arthritis in transgenic mice that express a PG-specific TCR on their T cells (Berlo et al., 2006). Therefore, we hypothesized that adding PG-specific $\mathrm{CD} 4^{+} \mathrm{T}$ cells to the endogenous pool of cartilage antigen-specific $\mathrm{CD} 4^{+} \mathrm{T}$ cells might exacerbate PGIA in wild type mice. This potential pro-inflammatory effect of PG-specific T cells in PGIA was assessed in two sets of experiments. In a first experiment $1 \times 10^{6}$ naïve PG-specific CD4 ${ }^{+}$ cells were transferred in PGIA. A group of mice receiving only PBS was used as untreated control. Also, $\mathrm{CD}^{+}$cells that were transduced with MSCV-GFP $\left(\mathrm{T}_{\mathrm{GFP}}\right)$, thus without any gene encoding an immunosuppressive molecule, were transferred in PGIA. These $\mathrm{T}_{\mathrm{GFP}}$ cells were used as a control for $T$ cells that were transduced to express immunosuppressive proteins as described later on. In a second experiment, $\mathrm{T}_{\mathrm{h}} 1$-differentiated and $\mathrm{T}_{\mathrm{GFP}}$ cells were transferred to test for any additive pro-inflammatory, arthritogenic effect. On day 20 , the day before the second arthritogenic PG-immunization, $1 \times 10^{6} \mathrm{~T}$ cells were transferred to each mouse.

Six days after transfer, the earliest clinical symptoms of arthritis were observed. Neither $1 \times 10^{6}$ naive PG-specific T cells (Fig. 2A, left panel) nor $1 \times 10^{6} \mathrm{PG}$-specific $\mathrm{T}_{\mathrm{GFP}}$ cells (Fig. $2 \mathrm{~A}$, right panel) induced exacerbation of arthritis severity during the course of disease and also the day of arthritis onset and the maximum arthritis severity observed during the experiment were not affected by these $\mathrm{T}$ cells. Moreover, PG-specific $\mathrm{T}_{\mathrm{h}} 1$ cells did not worsen inflammation either as shown in a second experiment (Fig. 2B, left panel and Table 2). In addition, these naive $T$ cells, $T_{G F P}$ cells or $T_{h} 1$ cells did not induce a higher incidence of arthritis (Fig. 3).

\subsection{Disease-suppressing effects of PG-specific transduced T cells and $T_{h} 2$ cells in PGIA}

The potential anti-inflammatory effect of PG-specific T cells that were either transduced to express immune modulatory agents or differentiated into $\mathrm{a}_{\mathrm{h}} 2$ phenotype, was assessed in PGIA similar to testing of the $T_{h} 1$ and naïve $P G$-specific $T$ cells described above. PG-specific CD4 ${ }^{+}$T cells were either transduced with IL-1RA, TNF$\alpha$ RIg, IL- 4 or differentiated to $\mathrm{T}_{\mathrm{h}} 2$ cells in vitro and $1 \times 10^{6}$ of these $\mathrm{T}$ cells were transferred in PGIA. Although they were expected to counteract the arthritogenic $\mathrm{T}_{\mathrm{h}} 1$ response, $\mathrm{T}_{\mathrm{h}} 2$ cells or $\mathrm{T}$ cells transduced with the gene expressing the $\mathrm{T}_{\mathrm{h}} 2$ characteristic cytokine IL- 4

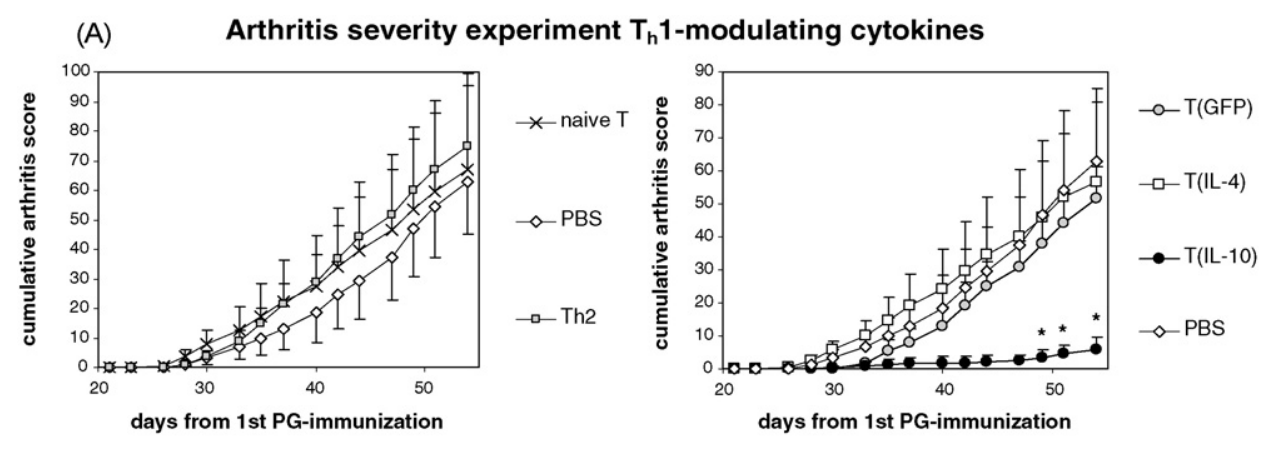

(B) Arthritis severity experiment IL-1 $\beta /$ TNF- $\alpha$-blocking cytokines
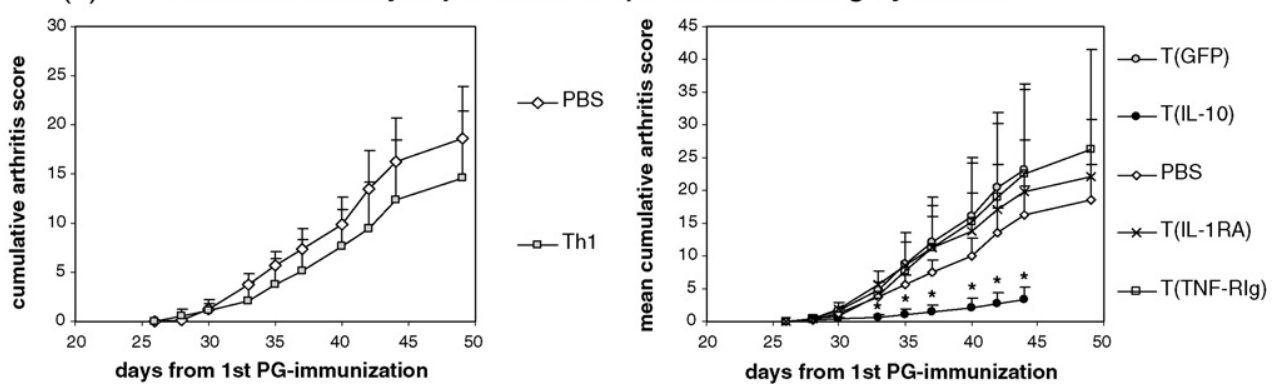

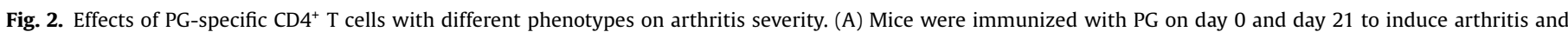

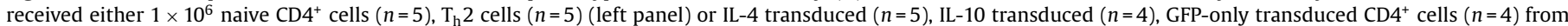

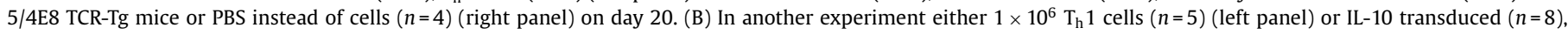

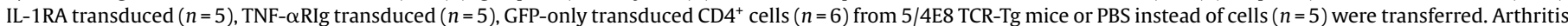
severity was scored by redness and swelling of the joints and the mean cumulative arthritis score is shown. ${ }^{*} p<0.05$ for groups compared with the PBS control group. 
Table 2

Arthritis onset, arthritis incidence and maximum arthritis severity

\begin{tabular}{|c|c|c|c|c|c|c|}
\hline & PBS & GFP & IL-10 & IL-4 & Naive & $\mathrm{T}_{\mathrm{h}} 2$ \\
\hline \multicolumn{7}{|c|}{$\mathrm{T}_{\mathrm{h}} 1$-modulating cytokines } \\
\hline Day of onset & $11( \pm 3.4)$ & $13.5( \pm 1.0)$ & $20.3( \pm 4.9)$ & $7.0( \pm 0.8)$ & $17.4( \pm 5.0)$ & $11.6( \pm 3.0)$ \\
\hline \multirow[t]{2}{*}{ Maximum severity } & $9.8( \pm 1.4)$ & $8.4( \pm 0.9)$ & $2.0( \pm 0.9)^{\mathrm{a}}$ & $6.2( \pm 2.9)$ & $9.4( \pm 2.7)$ & $9.3( \pm 2.2)$ \\
\hline & PBS & GFP & IL-10 & IL-1RA & TNF- $\alpha$ RIg & $\mathrm{T}_{\mathrm{h}} 1$ \\
\hline \multicolumn{7}{|l|}{ Blocking cytokines } \\
\hline Day of onset & $9.8( \pm 1.0)$ & $13.4( \pm 3.12)$ & $13.5( \pm 3.8)$ & $9.3( \pm 1.0)$ & $13.5( \pm 3.4)$ & $14.6( \pm 2.3)$ \\
\hline Maximum severity & $4.0( \pm 1.1)$ & $4.9( \pm 2.43)$ & $0.8( \pm 0.4)^{\mathrm{a}}$ & $4.0( \pm 1.4)$ & $4.9( \pm 2.4)$ & $3.4( \pm 1.2)$ \\
\hline
\end{tabular}

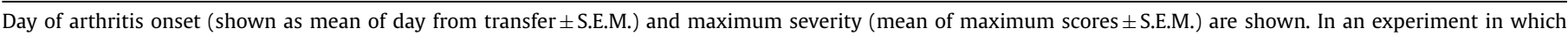

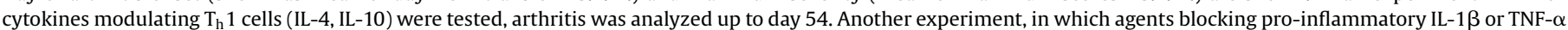

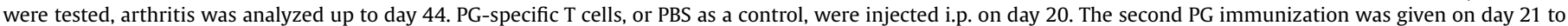
induce arthritis.

a $p<0.05$.

( $\mathrm{T}_{\mathrm{IL}-4}$ cells), did not suppress arthritis severity (Fig. 2A; left and right panel, respectively). Also day of disease onset and maximum arthritis severity observed were not affected compared to the PBS-control group as found in experiment 1 (Table 2). Moreover, PG-specific T cells transduced with IL-1RA/GFP ( $\mathrm{T}_{\text {IL-1RA }}$ cells) or TNF- $\alpha$ RIg/GFP ( $\mathrm{T}_{\mathrm{TNF}-\alpha \mathrm{RIg}}$ cells) did not have a beneficial effect on the course of arthritis (Fig. 2B, right panel) or on the day of onset and maximum arthritis severity observed (Table 2 ) as shown in the second experiment. Moreover, no effect was found on the cumulative incidence of arthritis for all of these T cells (Fig. 3).

So far, none of these transferred populations of $1 \times 10^{6}$ PGspecific $T$ cells expressing anti-inflammatory molecules were able to suppress inflammation in PG-induced arthritis. However, when PG-specific T cells were transduced with the IL-10 gene $\left(T_{\text {IL-10 }}\right.$ cells), these $\mathrm{T}$ cells significantly reduced arthritis severity during the course of disease in both experiments (right panels Fig. 2A and $\mathrm{B}$ ) compared with the PBS-control. In addition, maximum arthritis severity observed was significantly lower after transfer of PG-specific $\mathrm{T}_{\mathrm{IL}-10}$ cells (Table 2) and cumulative incidence was lower (Fig. 3, right panels) in mice that received $\mathrm{T}_{\mathrm{IL}-10}$ cells. Although PGspecific $\mathrm{T}_{\mathrm{IL}-10}$ cells tended to slightly delay the onset of disease, this effect on the day of arthritis onset was not significant. Altogether, these data indicate that IL-10 may be a very promising candidate to be expressed by antigen-specific $\mathrm{T}$ cells in order to suppress inflammation.

\subsection{Characterization of IL-10 transduced T cells}

To gain more insight in the differentiation and action of IL10 transduced $\mathrm{T}$ cells, we analyzed suppressive and phenotypic characteristics of these cells. IL-12p70 is one of the key cytokines involved in the induction pathway of arthritis (McInnes and Schett, 2007; Tarner et al., 2003). IL-12p70 is profoundly expressed by cells that present antigens to $\mathrm{T}$ cells, such as professional antigen-

(A) Arthritis incidence experiment $\mathrm{T}_{\mathrm{h}}$ 1-modulating cytokines
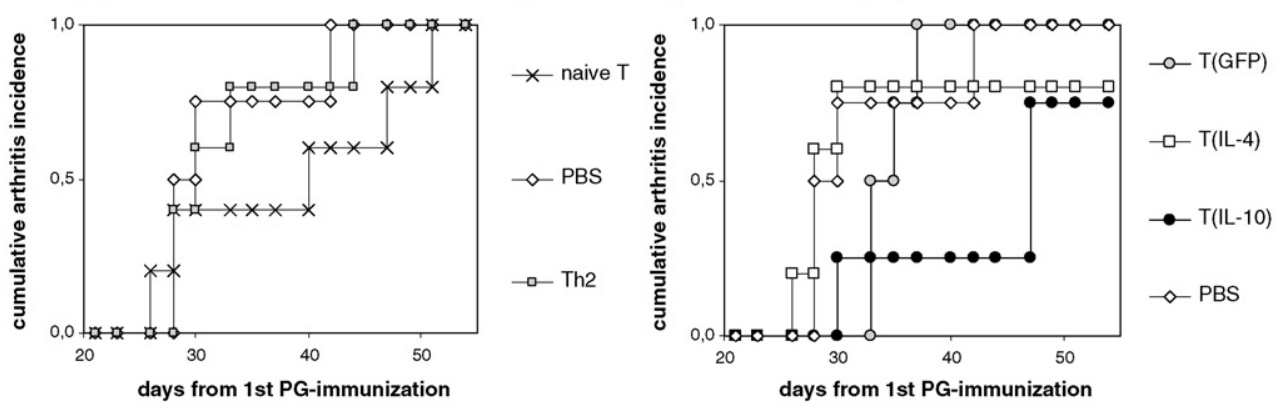

(B) Arthritis incidence experiment IL-1 $\beta / T N F-\alpha$-blocking cytokines
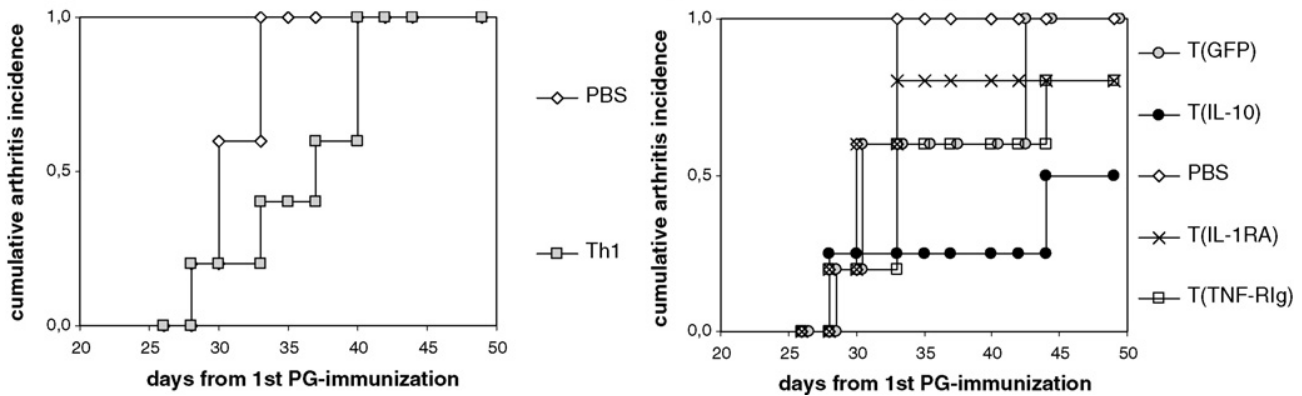

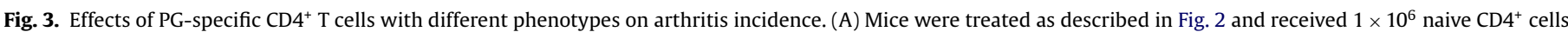

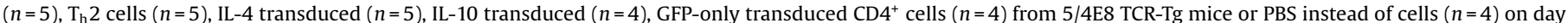

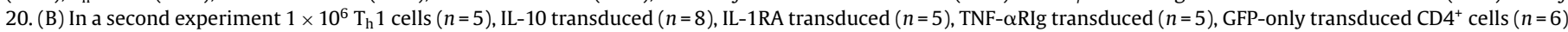

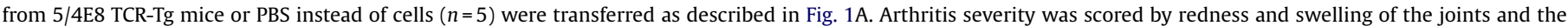
cumulative arthritis incidence score is shown. Graphs are split in two for convenience of understanding. 


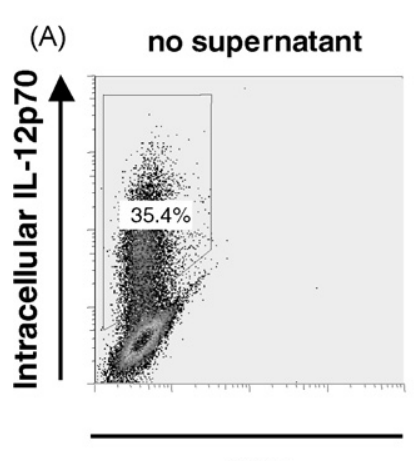

- LPS

(B)

control
$\mathrm{T}$ cells

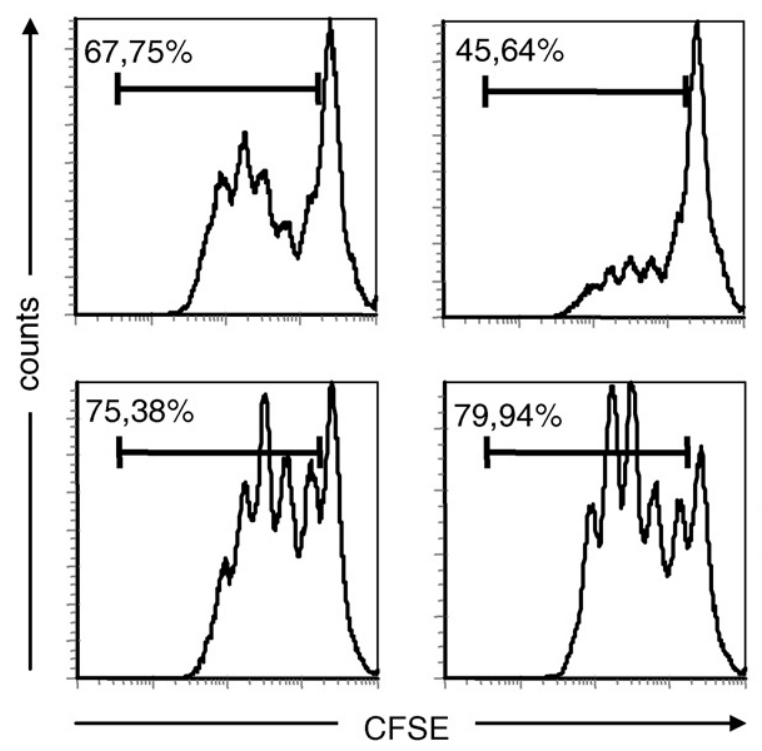

IL-10 transduced T cell supernatant
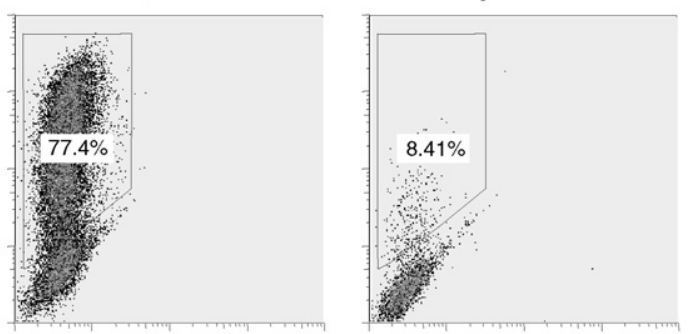

+ LPS with blocking

anti-IL-10 mAb

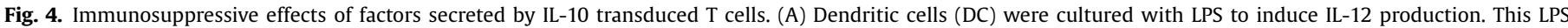

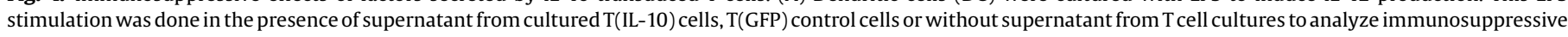

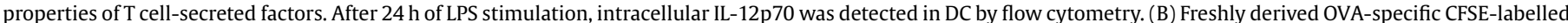

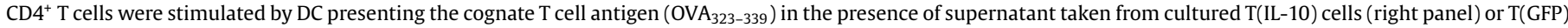

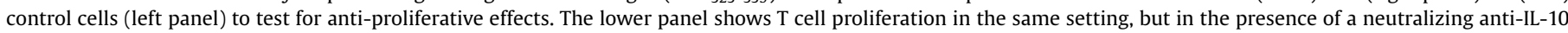
$\mathrm{mAb}$.

presenting dendritic cells (DC). Therefore, we tested whether $\mathrm{T}_{\mathrm{IL}-10}$ cells secrete factors that suppress IL-12p70 production in DC. For this, IL-12p70 production in DC was boosted with LPS for $24 \mathrm{~h}$ in the presence of supernatant derived from cultured $\mathrm{T}_{\mathrm{IL}-10}$ cells or control $\mathrm{T}_{\mathrm{GFP}}$ cells (Fig. 4A). Compared to supernatant from $\mathrm{T}_{\mathrm{GFP}}$ cells, $\mathrm{T}_{\mathrm{IL}-10}$ cells have a stronger capacity to suppress LPS-induced IL-12p70 production in DC as analyzed by flow cytometry for intracellular IL-12p70 after stimulation. However, compared to DC that were stimulated with LPS in the absence of T cell-derived culture supernatant, conditioned supernatant from cultured $\mathrm{T}_{\mathrm{GFP}}$ cells also seemed to suppress IL-12p70. This may be explained by the IL-4 that is produced during $\mathrm{T}$ cell culture (as described in Section 3.3) during CD3/CD28 stimulation and is known for its effects to suppress IL-12p70 production. In addition to suppressing IL-12p70, $\mathrm{T}_{\mathrm{IL}-10}$ cells suppressed proliferation of OVA-specific T cells responding to OVA-loaded DC (Fig. 4B). Supernatant from cultured $\mathrm{T}_{\mathrm{IL}-10}$ cells suppressed proliferation, indicating that $\mathrm{T}_{\mathrm{IL}-10}$ cells suppress through secreted factors. Since IL-10 was the most likely factor through which suppression was mediated, a neutralizing anti-IL-10 mAb was added to the assay to block the action of IL-10. Neutralizing IL-
10 completely abrogated the immunosuppressive effect, indicating that IL-10 is the major factor that is responsible for immunosuppression by $\mathrm{T}_{\mathrm{IL}-10}$ cells.

Because in vitro $\mathrm{T}_{\mathrm{IL}-10}$ cells regulated primarily through expression and secretion of IL-10, our data indicate that the $\mathrm{T}_{\mathrm{IL}-10}$ cells resemble $T_{\mathrm{r}} 1$ regulatory $\mathrm{T}$ cells. Therefore, we further characterized differentiation of PG-specific $\mathrm{T}_{\mathrm{IL}-10}$ cells in PG-induced arthritis. PGspecific $\mathrm{T}_{\mathrm{IL}-10}$ cells or control cells were transferred as described previously. Six days after transfer the transferred $C D 4^{+} \mathrm{T}$ cells were detected and isolated from spleens by CD4 and GFP expression with FACS. mRNA was extracted from these cells to quantify their expression of Foxp3 (the hallmark of natural $C D 4^{+} \mathrm{CD} 25^{+} \mathrm{T}_{\text {reg }}$ cells) and TGF- $\beta$ (hallmark of $\mathrm{T}_{\mathrm{h}} 3 \mathrm{~T}_{\text {reg }}$ cells) by RT-PCR. Both Foxp 3 and TGF- $\beta$ were not propagated in the $\mathrm{T}_{\mathrm{IL}-10}$ cells, compared to controls (Fig. 5). Rather, expression of these molecules was suppressed, indicating that $\mathrm{T}_{\mathrm{IL}-10}$ cells do not acquire a natural $\mathrm{T}_{\text {reg }}$ or a $\mathrm{T}_{\mathrm{h}} 3$ phenotype. Together with the finding that expression of IL-10 mRNA was still high in the $\mathrm{T}_{\mathrm{IL}-10}$ cells (data not shown), and because their action is mainly mediated through IL-10 (both characteristic for $\mathrm{T}_{\mathrm{r}} 1$ cells), the $\mathrm{T}_{\mathrm{IL}-10}$ cells most closely resemble a $\mathrm{T}_{\mathrm{r}} 1$ cell phenotype. 


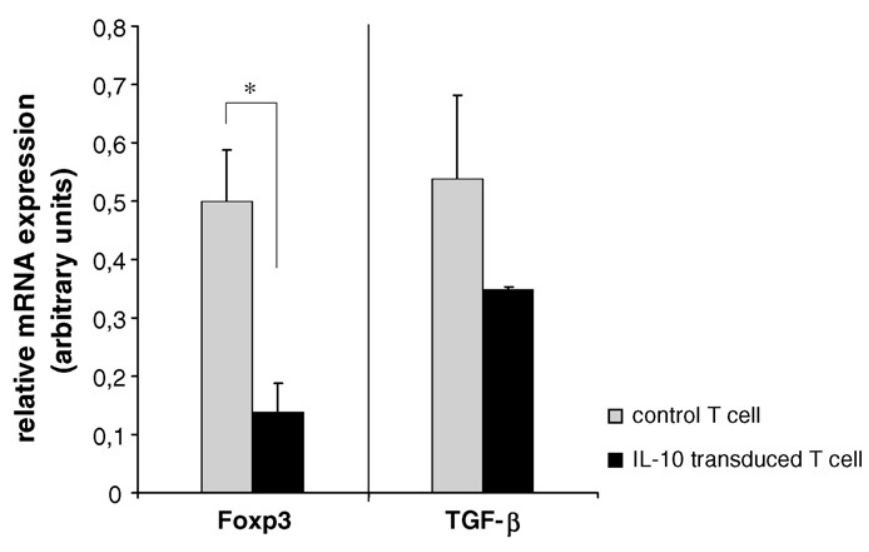

Fig. 5. Phenotypic analysis of expression of the regulatory markers Foxp 3 and TGF- $\beta$ in IL-10 transduced T cells after transfer in PG-induced arthritis. Mice were immunized with PG and received $2 \times 10^{6}$ IL-10 transduced PG-specific CD4 ${ }^{+} \mathrm{T}$ cells (black bars) or PG-specific CD4 $4^{+}$T controls (only GFP transduced, grey bars) as described in Fig. 2. After 6 days, mice were sacrificed and transferred T cells $\left(C D 4^{+} \mathrm{GFP}^{+}\right)$were isolated from spleens by FACS ( $n=3$ per group). Expression of Foxp3 (left) and TGF- $\beta$ (right) by the isolated T cells was done by quantitative RT-PCR. Expression levels are shown as arbitrary units normalized to expression of the house keeping gene HPRT. ${ }^{*} p<0.05$.

\section{Discussion}

Proteoglycan-induced arthritis is a chronic and progressive model of RA (Glant et al., 2003) and is characterized by a dominating $\mathrm{T}_{\mathrm{h}} 1$ response (Finnegan et al., 1999; Hollo et al., 2000; Kaplan et al., 2002; Buzas et al., 1995; Bardos et al., 2002). The generation of a TCR-specific mouse (Berlo et al., 2006, 2005) as a source for PG-specific CD4 ${ }^{+} \mathrm{T}$ cells allows for studies on $\mathrm{CD} 4^{+} \mathrm{T}$ cell-mediated functions in this arthritis model. In this study we examined the possibility to target inflammation in PGIA with ex vivo modulated $\mathrm{PG}$-specific $\mathrm{CD} 4^{+} \mathrm{T}$ cells. Because arthritogenic and PG-specific T cells can migrate not only to the lymphoid organs but also to inflamed joints (Mikecz and Glant, 1994), they may be suitable tools to deliver such anti-inflammatory agents at the site of inflammation. Application of (genetically) modified $\mathrm{CD} 4^{+}$ $\mathrm{T}$ cells expressing anti-inflammatory agents to successfully target autoimmune mediated inflammation was proposed and carried out previously (Tarner et al., 2003). However, this is the first study which combined immunomodulatory molecules expressed by primary arthritogenic $\mathrm{CD} 4^{+} \mathrm{T}$ cells, with a well defined specificity for a cartilage antigen, in a chronic and progressive arthritis driven by cartilage-specific immune responses.

To genetically modify $\mathrm{T}$ cells using a retroviral system we activated $\mathrm{T}$ cells with anti-CD3/anti-CD28 mAb-conjugated magnetic beads (Broeren et al., 2000). Rheumatic joints contain clonally expanded $\mathrm{T}$ cell populations. This indicates that these cells are specifically involved in the inflammatory auto-antigen specific immune response and these $\mathrm{T}$ cells may therefore be used for adoptive cellular gene therapy. The use of anti-CD3/anti-CD28stimulation by mAbs used for $\mathrm{T}$ cell activation is less time consuming than use of APC as has often been done since no APCs have to be sorted prior to and after T cell stimulation. This method turned out to be a very efficient method to stimulate $\mathrm{T}$ cells since transduction with retrovirus, which requires $\mathrm{T}$ cell division, resulted in up to $80 \%$ transduced T cells. Stimulation with anti-CD3/anti-CD28 mAbs resulted in a higher IFN- $\gamma$ response over an IL-4 response, which is indicative of $T_{h} 1$ cells as has been described before (Broeren et al., 2000). However, this phenotype could be skewed to a more pronounced $T_{h} 1$ phenotype or to a $T_{h} 2$ phenotype when either IL-12p70 and anti-IL-4 mAb or IL-4 and anti-IFN- $\gamma$ mAb were present during $\mathrm{T}$ cell activation, respectively.
This indicates that further (co-)stimulatory molecules or cytokines expressed by APCs are not crucial for T cell differentiation of IL- 4 or IFN- $\gamma$ responses in the presence of these cytokines, although they may enhance this differentiation (Rogers and Croft, 1999; Dong and Flavell, 2001).

Induction of PGIA requires a $\mathrm{T}_{\mathrm{h}} 1$ response (Finnegan et al., 1999; Kaplan et al., 2002) and can be achieved by transfer of PG-primed $\mathrm{CD}^{+} \mathrm{T}$ cells to lymphopenic hosts (Berlo et al., 2005; Buzas et al., 1995; Bardos et al., 2002). Moreover, TCR-Tg mice expressing a PG-specific TCR are more susceptible to PGIA (Berlo et al., 2006). Therefore, we reasoned that transfer of PG-specific $T_{h} 1$ cells to wild type recipients would exacerbate PGIA. Because in previous studies adoptively transferred $0.5-2 \times 10^{6} \mathrm{CD}^{+} \mathrm{T}$ cells transduced with several genes have been demonstrated to sort effects in different disease models (reviewed in van de Loo et al., 2004; Finnegan et al., 1999; Weisman, 2002; Robbins et al., 2003; Tarner et al., 2003), we anticipated that $1 \times 10^{6}$ cells would be sufficient to modulate PG-induced arthritis. However, $1 \times 10^{6} \mathrm{PG}$-specific $\mathrm{T}_{\mathrm{h}} 1$ cells did not promote disease development. Recently, it was shown that $T_{h} 1$ cells, and also $T_{h} 2$ cells, may block differentiation of $C D D^{+} T$ cells producing IL-17 ( $T_{h} 17$ cells), which is a newly identified T cell phenotype that is crucial for the induction of autoimmune disorders like arthritis (Wynn, 2005). Therefore, it is possible that PG-specific $T_{h 1}$ cells could prevent differentiation or activity of pro-inflammatory $\mathrm{T}_{\mathrm{h}} 17$ cells instead of exacerbating disease. No suppressive effect of $T_{h} 1$ cells on disease was observed either. Therefore, suppression of an arthritogenic $\mathrm{T}_{\mathrm{h}} 17$ response is unlikely. Moreover, naïve PG-specific

PG-specific $\mathrm{CD}^{+} \mathrm{T}$ cells that were transferred from highly arthritis susceptible TCR-Tg mice without prior ex vivo stimulation/differentiation to wild type mice with PGIA, exerted no clinical effects. Therefore, a likely explanation may be that the number $\left(1 \times 10^{6}\right)$ of PG-specific T cells added to the already existing pool of arthritogenic lymphocytes is not enough to exacerbate arthritis in wild type recipients.

Neither PG-specific $T_{h} 2$ cells nor PG-specific IL-4-transduced $\mathrm{T}$ cells suppressed arthritis, although $\mathrm{T}_{\mathrm{h}} 2$ cells and their derived cytokines like IL- 4 are well known to regulate $T_{h} 1$ responses in inflammatory diseases like PGIA (Finnegan et al., 1999, 2002; Kaplan et al., 2002). This is in contrast with studies where only $2 \times 10^{6}$ OVA-specific $\mathrm{T}_{\mathrm{h}} 2$ cells could suppress disease in an OVA-induced arthritis model (Maffia et al., 2004) or where antiinflammatory effects of collagen-specific $\mathrm{T}_{\mathrm{IL}-4}$ cells have been demonstrated in collagen-induced arthritis (CIA) (Tarner et al., 2002). Maybe the phenotype of such $T$ cells in our studies was not strong enough or the number of transferred T cells not sufficient to counteract on an arthritogenic immune response. Whereas in our study $1 \times 10^{6}$ primary $\mathrm{CD}^{+} \mathrm{T}$ cells were used, in CIA and in other models $1 \times 10^{6} \mathrm{CD}^{+} \mathrm{T}$ cell hybridoma's were used as a source of antigen-specific $\mathrm{T}$ cells. Such hybridoma's proliferate without antigenic-stimulation. Therefore, such hybridoma's constantly proliferate irrespective of their location and will therefore probably be present in larger numbers secreting higher amounts of cytokines. Discrepancy between our findings and previously documented findings may also be explained by differences between models. Although both CIA and PGIA are dominated by $T_{h} 1$ cells, these models may be slightly differently regulated in terms of $T_{h} 1$ and $T_{h} 2$ immunity as the natural immunological backgrounds of the mice used for these models differ (Glant et al., 2003). In addition, a likely explanation may be found in the differences of $\mathrm{CD}^{+} \mathrm{T}$ cells used in different studies.

IL-1 $\beta$ and TNF- $\alpha$ have prominent pro-inflammatory functions within the joint tissue and act downstream $\mathrm{T}_{\mathrm{h} 1}$ cell-mediated immunity (McInnes and Schett, 2007). Blocking the biological activ- 
ities of these cytokines with IL-1RA or TNF- $\alpha$ R respectively has been demonstrated a successful approach to ameliorate inflammation in a wide range of arthritis models and other models for autoimmune mediated inflammation (van de Loo et al., 2004). Agents blocking these cytokines have also been shown to suppress arthritis when expressed by transduced cartilage antigen-specific $\mathrm{CD}^{+}{ }^{+} \mathrm{T}$ cell hybridoma's (Smith et al., 2003) or synovial fibroblasts (Bandara et al., 1993). However, in our study $1 \times 10^{6} \mathrm{~T}_{\mathrm{IL}-1 \mathrm{RA}}$ or $\mathrm{T}_{\mathrm{TNF}-\alpha \mathrm{RIg}}$ cells did not suppress clinical symptoms of inflammation in PGIA, although IL-1RA and TNF- $\alpha$ RIg were expressed functionally. Again, these contrasting findings may be explained by the use of different models, the use of T cell hybridoma's or the number of $T$ cells transferred.

IL-10 and TGF- $\beta$ have been described as the major immunosuppressive cytokines required for different subsets of regulatory $\mathrm{T}$ cells ( $\mathrm{T}_{\text {reg }}$ cells) to down regulate pro-inflammatory immune responses that lead to autoimmune disease, allergy or exaggerated responses to pathogens. Like IL-4, IL-10 has been shown to suppress PGIA when administered systemically (Finnegan et al., 1999). The immunosuppressive effects of such daily systemic cytokine administration ceased when administration was abrogated (Finnegan et al., 1999). However, unlike PG-specific $\mathrm{T}_{\text {IL-4 }}$ cells, one injection of PG-specific $T_{\text {IL-10 }}$ cells showed significant beneficial effects on PGIA. Although $\mathrm{T}_{\mathrm{IL}-10}$ cells resembled $\operatorname{Tr} 1$ cells expressing a high amount of IL-10, systemic levels of IL-10 protein in vivo were below detection level (data not shown). Moreover, low numbers $(<0.002 \%)$ of $\mathrm{T}_{\text {IL-10 }}$ cells were found in the spleen, and also in the inflamed joints (data not shown). Altogether these data indicate that the $\mathrm{T}$ cells focus the action of IL-10 to relevant tissues over a sustained period rather than providing a massive overall, systemic increase of IL-10 expression as with systemic administration of cytokines.

Because of all the anti-inflammatory agents tested IL-10 was the only one that suppressed arthritis when expressed by transduced PG-specific T cells, IL-10 may be a very promising cytokine to be used in $\mathrm{T}$ cell mediated intervention in arthritis. Not only transduction with the IL-10 gene, but also ways to promote IL-10 producing $\mathrm{T}_{\text {reg }}$ cells have been very promising in interventions in inflammatory diseases (Groux et al., 1997; Bluestone, 2005; Barrat et al., 2002). Therefore, mechanisms that propagate the expression of IL-10 to alter the autoimmune response that sustains inflammation, such as production of IL-12, may be more effective than just blocking the resulting downstream effects such as expression of pro-inflammatory molecules that are amplified by this autoimmune response.

\section{Acknowledgements}

The authors thank Dr. Ger Arkesteijn for intensive help with sorting of cells. The authors are also grateful to Drs. Berent Prakken, Mariette Oosterwegel and Lonneke Vervelde for helpful comments and Dr. Albert Marsman and colleagues of the hospital Hilversum (Hilversum, the Netherlands) for their help in obtaining essential materials.

\section{References}

Bandara, G., Mueller, G.M., Galea-Lauri, J., Tindal, M.H., Georgescu, H.I., Suchanek, M.K., Hung, G.L., Glorioso, J.C., Robbins, P.D., Evans, C.H., 1993. Intraarticular expression of biologically active interleukin 1-receptor-antagonist protein by ex vivo gene transfer. Proc. Natl. Acad. Sci. U.S.A. 90, 10764-10768.

Bardos, T., Mikecz, K., Finnegan, A., Zhang, J., Glant, T.T., 2002. T and B cell recovery in arthritis adoptively transferred to SCID mice: antigen-specific activation is required for restoration of autopathogenic CD4+ Th1 cells in a syngeneic system. J. Immunol. 168, 6013-6021.

Barrat, F.J., Cua, D.J., Boonstra, A., Richards, D.F., Crain, C., Savelkoul, H.F., de Waal-Malefyt, R., Coffman, R.L., Hawrylowicz, C.M., O'Garra, A., 2002. In vitro generation of interleukin 10-producing regulatory CD4(+) T cells is induced by immunosuppressive drugs and inhibited by T helper type 1 (Th1)- and Th2inducing cytokines. J. Exp. Med. 195, 603-616.

Berlo, S.E., van Kooten, P.J., Ten Brink, C.B., Hauet-Broere, F., Oosterwegel, M.A. Glant, T.T., Van Eden, W., Broeren, C.P., 2005. Naive transgenic T cells expressing cartilage proteoglycan-specific TCR induce arthritis upon in vivo activation. J. Autoimmun. 25, 172-180.

Berlo, S.E., Guichelaar, T., Ten Brink, C.B., van Kooten, P.J., Hauet-Broeren, F., Ludanyi, K., van Eden, W., Broeren, C.P., Glant, T.T., 2006. Increased arthritis susceptibility in cartilage proteoglycan-specific T cell receptor-transgenic mice. Arthritis Rheum. 54, 2423-2433.

Bluestone, J.A., 2005. Regulatory T-cell therapy: is it ready for the clinic? Nat. Rev. Immunol. 5, 343-349.

Brand, D.D., Kang, A.H., Rosloniec, E.F., 2003. Immunopathogenesis of collagen arthritis. Springer Semin. Immunopathol. 25, 3-18.

Broeren, C.P., Gray, G.S., Carreno, B.M., June, C.H., 2000. Costimulation light: activation of CD4+ T cells with CD80 or CD86 rather than anti-CD28 leads to a Th2 cytokine profile. J. Immunol. 165, 6908-6914.

Buzas, E.I., Brennan, F.R., Mikecz, K., Garzo, M., Negroiu, G., Hollo, K., Cs-Szabo, G., Pintye, E., Glant, T.T., 1995. A proteoglycan (aggrecan)-specific T cell hybridoma induces arthritis in BALB/c mice. J. Immunol. 155, 2679-2687.

Costa, G.L., Benson, J.M., Seroogy, C.M., Achacoso, P., Fathman, C.G., Nolan, G.P., 2000 Targeting rare populations of murine antigen-specific T lymphocytes by retroviral transduction for potential application in gene therapy for autoimmune disease. J. Immunol. 164, 3581-3590.

Dong, C., Flavell, R.A., 2001. Th1 and Th2 cells. Curr. Opin. Hematol. 8, 47-51.

Espevik, T., Nissen-Meyer, J., 1986. A highly sensitive cell line, WEHI 164 clone 13, for measuring cytotoxic factor/tumor necrosis factor from human monocytes. J. Immunol. Methods 95, 99-105.

Finnegan, A., Mikecz, K., Tao, P., Glant, T.T., 1999. Proteoglycan (aggrecan)-induced arthritis in BALB/c mice is a Th1-type disease regulated by Th2 cytokines. J. Immunol. 163, 5383-5390.

Finnegan, A., Grusby, M.J., Kaplan, C.D., O’Neill, S.K., Eibel, H., Koreny, T., Czipri, M. Mikecz, K., Zhang, J., 2002. IL-4 and IL-12 regulate proteoglycan-induced arthritis through Stat-dependent mechanisms. J. Immunol. 169, 3345-3352.

Glant, T.T., Finnegan, A., Mikecz, K., 2003. Proteoglycan-induced arthritis: immune regulation, cellular mechanisms, and genetics. Crit. Rev. Immunol. 23, 199-250.

Goodstone, N.J., Doran, M.C., Hobbs, R.N., Butler, R.C., Dixey, J.J., Ashton, B.A., 1996. Cellular immunity to cartilage aggrecan core protein in patients with rheumatoid arthritis and non-arthritic controls. Ann. Rheum. Dis. 55, 40-46.

Groux, H., O’Garra, A., Bigler, M., Rouleau, M., Antonenko, S., de Vries, J.E., Roncarolo, M.G., 1997. A CD4+ T-cell subset inhibits antigen-specific T-cell responses and prevents colitis. Nature 389, 737-742.

Guerassimov, A., Zhang, Y., Banerjee, S., Cartman, A., Leroux, J.Y., Rosenberg, L.C. Esdaile, J., Fitzcharles, M.A., Poole, A.R., 1998. Cellular immunity to the G1 domain of cartilage proteoglycan aggrecan is enhanced in patients with rheumatoid arthritis but only after removal of keratan sulfate. Arthritis Rheum. 41, 1019-1025

Hanyecz, A., Berlo, S.E., Szanto, S., Broeren, C.P., Mikecz, K., Glant, T.T., 2004. Achievement of a synergistic adjuvant effect on arthritis induction by activation of innate immunity and forcing the immune response toward the Th1 phenotype. Arthritis Rheum. 50, 1665-1676.

Hollo, K., Glant, T.T., Garzo, M., Finnegan, A., Mikecz, K., Buzas, E., 2000. Complex pattern of Th1 and Th2 activation with a preferential increase of autoreactive Th1 cells in BALB/c mice with proteoglycan (aggrecan)-induced arthritis. Clin. Exp. Immunol. 120, 167-173.

Kaplan, C., Valdez, J.C., Chandrasekaran, R., Eibel, H., Mikecz, K., Glant, T.T., Finnegan, A., 2002. Th1 and Th2 cytokines regulate proteoglycan-specific autoantibody isotypes and arthritis. Arthritis Res. 4, 54-58.

Kramer, R., Zhang, Y., Gehrmann, J., Gold, R., Thoenen, H., Wekerle, H., 1995. Gene transfer through the blood-nerve barrier: NGF-engineered neuritogenic T lymphocytes attenuate experimental autoimmune neuritis. Nat. Med. 1, 1162-1166.

Li, N.L., Zhang, D.Q., Zhou, K.Y., Cartman, A., Leroux, J.Y., Poole, A.R., Zhang, Y.P., 2000. Isolation and characteristics of autoreactive $T$ cells specific to aggrecan G1 domain from rheumatoid arthritis patients. Cell Res. 10, 39-49.

Maffia, P., Brewer, J.M., Gracie, J.A., Ianaro, A., Leung, B.P., Mitchell, P.J., Smith, K.M., McInnes, I.B., Garside, P., 2004. Inducing experimental arthritis and breaking self-tolerance to joint-specific antigens with trackable, ovalbumin-specific $T$ cells. J. Immunol. 173, 151-156.

McInnes, I.B., Schett, G., 2007. Cytokines in the pathogenesis of rheumatoid arthritis. Nat. Rev. Immunol. 7, 429-442.

Mikecz, K., Glant, T.T., 1994. Migration and homing of lymphocytes to lymphoid and synovial tissues in proteoglycan-induced murine arthritis. Arthritis Rheum. 37, 1395-1403.

Oh, J.W., Seroogy, C.M., Meyer, E.H., Akbari, O., Berry, G., Fathman, C.G., Dekruyff, R.H., Umetsu, D.T., 2002. CD4 T-helper cells engineered to produce IL-10 prevent allergen-induced airway hyperreactivity and inflammation. J. Allergy Clin. Immunol. 110, 460-468.

O’Neill, S.K., Shlomchik, M.J., Glant, T.T., Cao, Y., Doodes, P.D., Finnegan, A., 2005 Antigen-specific B cells are required as APCs and autoantibody-producing cells for induction of severe autoimmune arthritis. J. Immunol. 174, 3781-3788.

Openshaw, P., Murphy, E.E., Hosken, N.A., Maino, V., Davis, K., Murphy, K., O’Garra A., 1995. Heterogeneity of intracellular cytokine synthesis at the single-cell level in polarized T helper 1 and T helper 2 populations. J. Exp. Med. 182, 13571367. 
Robbins, P.D., Evans, C.H., Chernajovsky, Y., 2003. Gene therapy for arthritis. Gene Ther. 10, 902-911.

Rogers, P.R., Croft, M., 1999. Peptide dose, affinity, and time of differentiation can contribute to the Th1/Th2 cytokine balance. J. Immunol. 163, 1205-1213.

Skapenko, A., Leipe, J., Lipsky, P.E., Schulze-Koops, H., 2005. The role of the T cell in autoimmune inflammation. Arthritis Res. Ther. 7 (Suppl. 2), S4-14.

Smeets, R.L., Joosten, L.A., Arntz, O.J., Bennink, M.B., Takahashi, N., Carlsen, H., Martin, M.U., van den Berg, W.B., van de Loo, F.A., 2005. Soluble interleukin-1 receptor accessory protein ameliorates collagen-induced arthritis by a different mode of action from that of interleukin-1 receptor antagonist. Arthritis Rheum. 52, 2202-2211.

Smith, R., Tarner, I.H., Hollenhorst, M., Lin, C., Levicnik, A.U., Fathman, C.G., Nolan, G.P., 2003. Localized expression of an anti-TNF single-chain antibody prevents development of collagen-induced arthritis. Gene Ther. 10, 1248-1257.

Tarner, I.H., Nakajima, A., Seroogy, C.M., Ermann, J., Levicnik, A., Contag, C.H., Fathman, C.G., 2002. Retroviral gene therapy of collagen-induced arthritis by local delivery of IL-4. Clin. Immunol. 105, 304-314.
Tarner, I.H., Slavin, A.J., McBride, J., Levicnik, A., Smith, R., Nolan, G.P., Contag, C.H. Fathman, C.G., 2003. Treatment of autoimmune disease by adoptive cellular gene therapy. Ann. N. Y. Acad. Sci. 998, 512-519.

ter Steege, J., Vianen, M., van Bilsen, J., Bijlsma, J., Lafeber, F., Wauben, M., 2003. Identification of self-epitopes recognized by $\mathrm{T}$ cells in rheumatoid arthritis demonstrates matrix metalloproteinases as a novel T cell target. J. Rheumatol. 30, 1147-1156.

van de Loo, F.A., Smeets, R.L., van den Berg, W.B., 2004. Gene therapy in animal models of rheumatoid arthritis: are we ready for the patients? Arthritis Res. Ther. 6, 183-196.

Weisman, M.H., 2002. What are the risks of biologic therapy in rheumatoid arthritis? An update on safety. J. Rheumatol. Suppl. 65, 33-38.

Wynn, T.A., 2005. $\mathrm{T}(\mathrm{H})-17$ : a giant step from $\mathrm{T}(\mathrm{H}) 1$ and $\mathrm{T}(\mathrm{H}) 2$. Nat. Immunol. 6, 1069-1070. 